\title{
Assessment of Heavy Metals in Rana esculenta Organs from River Guma, Benue State Nigeria
}

\author{
Ugbidye Shaapera, Lami A. Nnamonu, Ishaq S. Eneji* \\ Department of Chemistry, University of Agriculture, Makurdi, Benue State Nigeria \\ Email: *eneji3@yahoo.com
}

Received June 27, 2013; revised July 20, 2013; accepted September 5, 2013

Copyright (C) 2013 Ugbidye Shaapera et al. This is an open access article distributed under the Creative Commons Attribution License, which permits unrestricted use, distribution, and reproduction in any medium, provided the original work is properly cited.

\begin{abstract}
The concentrations of seven heavy metals ( $\mathrm{Pb}, \mathrm{Cu}, \mathrm{Zn}, \mathrm{Cr}, \mathrm{Fe}, \mathrm{Cd}$ and $\mathrm{Mn}$ ) were determined in the organs of Rana esculenta (frog) obtained from River Guma, Benue State of Nigeria using Atomic Absorption Spectrophotometer. The analysis of the triplicate experiments showed that the intestine contained the lowest concentration (25.9\%) of all the heavy metals detected, followed by the skin (30.5\%), while the liver contained the highest concentration (43.6\%). In all the frog organs, Fe had the highest concentration in the liver, followed by skin and lowest in the intestine. The trend of the heavy metals concentration in the organs can be represented as: $\mathrm{Fe}>\mathrm{Mn}>\mathrm{Pb}>\mathrm{Zn}>\mathrm{Cu}>\mathrm{Cr}>\mathrm{Cd}$. The concentrations of all the metals in the liver, skin and intestine of the frog were found to be statistically significant. Generally, the levels of $\mathrm{Pb}, \mathrm{Fe}, \mathrm{Cr}$ and $\mathrm{Mn}$ in all the samples were analyzed above the tolerance limits by the WHO with exception of $\mathrm{Cd}, \mathrm{Cu}$ and $\mathrm{Zn}$ that were below the permissible limits in the samples.
\end{abstract}

Keywords: Frog; Heavy Metals; Intestine; Liver; Skin

\section{Introduction}

As a result of increasing anthropogenic activities, heavy metals pollution of soil, water, and atmosphere represents a growing environmental problem affecting food quality and human health. Heavy metals may enter the food chain as a result of their uptake by edible plants, thus, the determination of heavy metals in environmental samples is important [1]. Heavy metals from soil enter plants primarily through the root system. Therefore, plant roots are the most important sites for uptake of chemicals from soil.

Heavy metals may have significantly toxic and hazardous effects on human health, especially cadmium and lead, as non-essential elements [2]. Cadmium is mobile in soil systems and very available to plants. Plant species differ widely in their tendency to accumulate cadmium.

Vinodhini, et al. [3] investigated the bioaccumulation of heavy metals in organs of fresh water fish Cyprinus carpio for a period of 28 days. The reported order of heavy metal accumulation in gills and liver was $\mathrm{Cd}>\mathrm{Pb}$ $>\mathrm{Ni}>\mathrm{Cr}$ and $\mathrm{Pb}>\mathrm{Cd}>\mathrm{Ni}>\mathrm{Cr}$, respectively. For kidney and flesh tissues, the order was $\mathrm{Pb}>\mathrm{Cd}>\mathrm{Cr}>\mathrm{Ni}$ and $\mathrm{Pb}>\mathrm{Cr}>\mathrm{Cd}>\mathrm{Ni}$. In all heavy metals, the bioac-

"Corresponding author. cumulation of lead and cadmium proportion was significantly increased in the tissues of Cyprinus carpio. Emmanuel, et al. [4] studied the macro and trace element accumulation in edible crabs and frogs in Alaro stream ecosystem, Ibadan and observed that the liver of the edible frogs showed higher concentrations of $\mathrm{Cu}, \mathrm{Mo}$, and $\mathrm{Cd}$ while $\mathrm{Na}, \mathrm{Mg}, \mathrm{K}, \mathrm{V}, \mathrm{Mn}, \mathrm{Fe}, \mathrm{Co}, \mathrm{Zn}$ and $\mathrm{Pb}$ were higher than the other organs in Rana esculentus.

Canbek, et al. [5] reported the preliminary assessment of heavy metals in water and some cyprinidae species from the Porsuk River in the Northwest of Turkey that suffer inputs from industrial and mining activities. The levels of some heavy metals ( $\mathrm{Mn}, \mathrm{Cr}, \mathrm{Cd}, \mathrm{As}, \mathrm{Ni}$ and $\mathrm{Pb}$ ) were analyzed in coal and sediment samples from River Ekulu in Enugu. The assessment of heavy metal contamination in sediments of Ase River, Niger Delta has been also investigated [6]. The accumulation pattern of heavy metals in the sediment follows the order $\mathrm{Fe}>\mathrm{Mn}$ $>\mathrm{Zn}>\mathrm{Ni}>\mathrm{Pb}>\mathrm{Cu}>\mathrm{Cd}>\mathrm{Cr}$. The levels of heavy metals were similar to levels found in unpolluted sediments and continental crust except for Cd. Such sediment system is at risk of cadmium pollution. Akan, et al. [7] investigated the distribution of heavy metals in the liver, kidney and muscle of cow, sheep, goat and chicken from Kasuwan shanu market in Maiduguri metropolis, Borno 
State Nigeria. They reported that the concentrations of all the metals were within the tolerance limits with the exception of $\mathrm{Cr}$ and $\mathrm{Pb}$, which were higher than standard limits. Ilona, et al. [8] investigated the effect of high concentrations of molybdenum, Chromium and Cadmium ions on the metamorphosis of Eurasian marsh frog Pelopyhax ridibundus under laboratory conditions. The effects of those metals at concentration exceeding maximum permissible concentration on the growth, survival and erythrocytes morphology of tadpole and young frogs have been determined. Luo, et al. [9] found the frog malformation in a number of sites across to Lake Champlain basin. Eneji [10] analyzed river water samples from different locations along the River Benue for twelve consecutive months. The results revealed that most of the parameters determined fall within the WHO acceptable standards for drinking water, except for $\mathrm{Cr}, \mathrm{Cd}$ and $\mathrm{Pb}$. Heavy metals concentration follows the trend: $\mathrm{Fe}>\mathrm{Cr}>$ $\mathrm{Pb}>\mathrm{Mn}>\mathrm{Zn}>\mathrm{Cu}>\mathrm{Cd}$. Eneji, et al. [11] also determined the concentration of these metals in the gills, intestine and muscle tissues of two fish species; Tilapia zilli and Clarias gariepinus obtained from up and down streams of the River Benue. They reported the percentage composition of total heavy metals in the fish organs to be $52.2 \%$ in the gills, $26.3 \%$ in the intestine and $21.5 \%$ in the muscle tissue in Tilapia zilli and contain $40.3 \%$ in the gills, $31.6 \%$ in the intestine and $28.1 \%$ in the muscle tissues of Clarias gariepinus. The objectives of this research are to establish baseline data and provide a basis for prediction of the consequences of heavy metals contamination in the river Guma and to determine heavy metals concentration in frog from river Guma.

\section{Materials and Methods}

\section{Sampling}

The frogs were collected along the bank of River Guma with geographical coordinates of $07.80700^{\circ}$ North and $008.65756^{\circ}$ East. The time of sampling was between 7:00 pm - 8:00 pm, when they came out to feed on insects and other smaller organisms. A total of 20 mature frog samples with mean weight of $150 \pm 3 \mathrm{~g}$ and mean length $26 \pm$ $2 \mathrm{~cm}$ were obtained from the sampling station and stored in an ice box in order to maintain the freshness and later transported ( $1 \frac{1}{2}$ hours) to the laboratory for dissection to obtain skin, intestine and liver. The frog samples organ (skin, intestine and liver) were oven dried separately for an hour to constant weight at $105^{\circ} \mathrm{C}$. The organs were pooled separately according to tissue type and milled with a mortar and pestle. They were put in dry labeled plastic containers and stored in desiccators until digestion. A procedure similar to that described by Poldoski [12] was used to digest the samples. This involves digesting
$10 \mathrm{~g}$ portion of the ground samples with $10 \mathrm{~mL} \mathrm{HNO}_{3}$ and $2 \mathrm{~mL} \mathrm{HClO}_{4}$. The residue was dissolved and diluted with $0.2 \% \mathrm{v} / \mathrm{v} \mathrm{HNO}_{3}$ to $20 \mathrm{~mL}$ and made up to $100 \mathrm{~mL}$ with distilled water. The digest was stored in pre-cleaned polyethylene bottles until analysis using atomic absorption spectrophotometer (AAS 6800 Shimadzu).

\section{Results and Discussion}

The mean concentrations of heavy metals in the intestine, skin and liver of frogs from River Guma Benue state are presented in Table 1. Pb levels ranged between $1.89 \pm$ 1.45 and $1.27 \pm 0.24 \mathrm{mg} / \mathrm{kg} ; 0.68 \pm 0.20$ and $0.04 \pm 0.04$ $\mathrm{mg} / \mathrm{kg} \mathrm{Cu} ; 1.81 \pm 0.20$ and $0.04 \pm 0.01 \mathrm{mg} / \mathrm{kg} \mathrm{Zn;} 0.11 \pm$ 0.03 and $0.06 \pm 0.01 \mathrm{mg} / \mathrm{kg} \mathrm{Cr} ; 114 \pm 3$ and $25.9 \pm 27.5$ $\mathrm{mg} / \mathrm{kg} \mathrm{Fe} ; 0.04 \pm 0.01$ and $0.02 \pm 0.00 \mathrm{mg} / \mathrm{kg} \mathrm{Cd}$ and $\mathrm{Mn}$ $3.94 \pm 0.97$ and $0.32 \pm 0.15 \mathrm{mg} / \mathrm{kg}$.

The concentration of $\mathrm{Pb}$ in liver is the highest (1.89 $\mathrm{mg} / \mathrm{kg})$, followed by intestine $(1.88 \mathrm{mg} / \mathrm{kg})$ and skin (1.53 mg/kg) as presented in Figure 1. Cu has a concentration of $(0.68 \mathrm{mg} / \mathrm{kg})$ in liver which is the highest, followed by the intestine with the mean concentration of $(0.04 \mathrm{mg} / \mathrm{kg})$ and no $\mathrm{Cu}$ accumulation in the skin of the frog (Figure 2). Zn has the highest level in the intestine $(1.81 \mathrm{mg} / \mathrm{kg})$ while the concentration was the same in liver and skin $(1.50 \mathrm{mg} / \mathrm{kg})$ of the frog as presented in Figure 3. The concentration for $\mathrm{Cr}$ is the same in both liver and skin of the frog $(0.06 \mathrm{mg} / \mathrm{kg})$ but higher in the intestine $(0.11 \mathrm{mg} / \mathrm{kg})$, as displayed in Figure 4 . Fe has the highest Concentration of $(114 \mathrm{mg} / \mathrm{kg})$ in liver, followed by the skin $(76.1 \mathrm{mg} / \mathrm{kg})$ and intestine $(63.0 \mathrm{mg} / \mathrm{kg})$ as depicted in Figure 5. Figure 6 shows that $\mathrm{Cd}$ has the

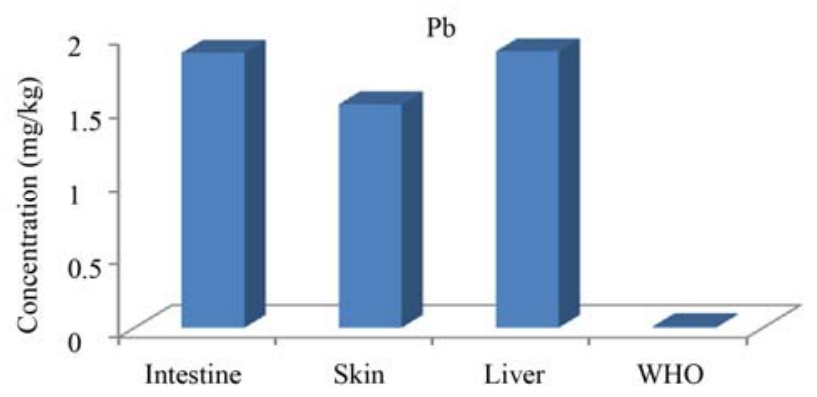

Figure 1. Distribution of lead in the organs of Rana esculenta from River Guma.

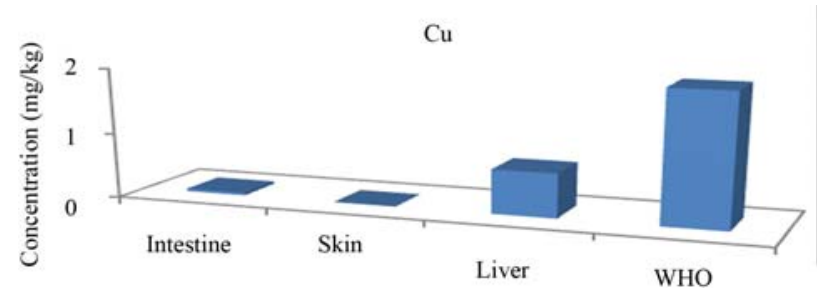

Figure 2. Distribution of copper in the organs of Rana esculenta from River Guma. 


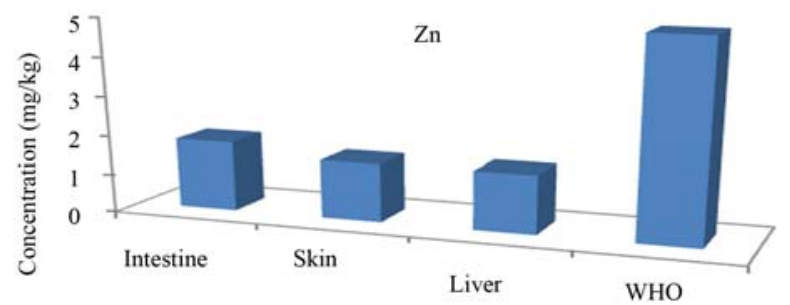

Figure 3. Distribution of Zinc in the organs of Rana esculenta from River Guma.

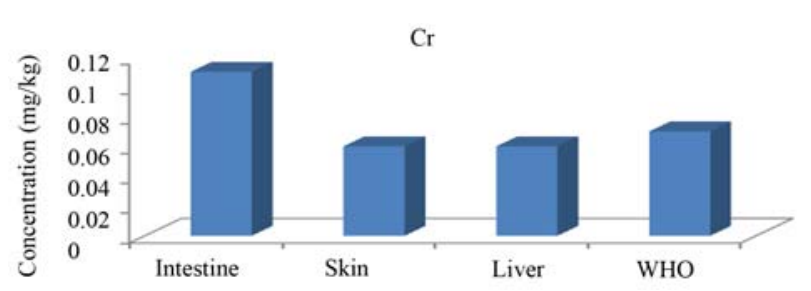

Figure 4. Distribution of Chromium in the organs of Rana esculenta from River Guma.

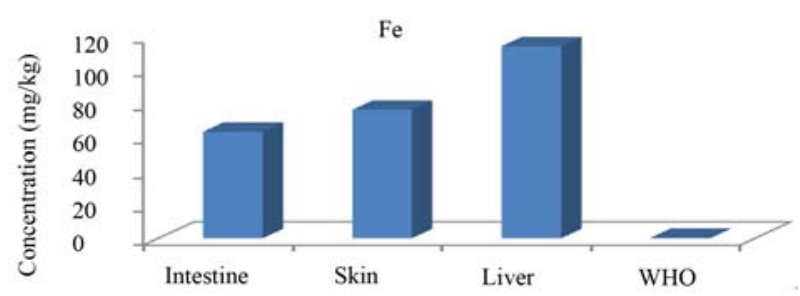

Figure 5. Distribution of Iron in the organs of Rana esculenta from River Guma.

Table 1. Distribution of heavy metals in Frog, water and sediment of River Guma.

\begin{tabular}{cccc}
\hline \multirow{2}{*}{ Element } & \multicolumn{3}{c}{ Samples $(\mathrm{mg} / \mathrm{kg})$} \\
\cline { 2 - 4 } & Frog & Water & Sediment \\
\hline $\mathrm{Pb}$ & $1.77 \pm 0.44$ & $1.27 \pm 0.24$ & $1.74 \pm 0.83$ \\
$\mathrm{Cu}$ & $0.36 \pm 0.03$ & $\mathrm{ND}$ & $\mathrm{ND}$ \\
$\mathrm{Zn}$ & $1.60 \pm 0.30$ & $0.04 \pm 0.01$ & $0.22 \pm 0.02$ \\
$\mathrm{Cr}$ & $0.08 \pm 0.03$ & $0.10 \pm 0.05$ & $0.11 \pm 0.05$ \\
$\mathrm{Fe}$ & $84.3 \pm 30.2$ & $35.9 \pm 34.8$ & $25.9 \pm 27.5$ \\
$\mathrm{Cd}$ & $0.03 \pm 0.01$ & $0.03 \pm 0.00$ & $0.03 \pm 0.03$ \\
$\mathrm{Mn}$ & $2.95 \pm 0.91$ & $0.32 \pm 0.15$ & $2.05 \pm 1.25$ \\
\hline
\end{tabular}

Note: ND means not detected.

highest concentration in liver $(0.04 \mathrm{mg} / \mathrm{kg})$, followed by the skin $(0.03 \mathrm{mg} / \mathrm{kg})$ and intestine $(0.02 \mathrm{mg} / \mathrm{kg})$. The concentration of Mn was highest in the skin $(3.94 \mathrm{mg} / \mathrm{kg})$, followed by intestine $(3.87 \mathrm{mg} / \mathrm{kg})$ and liver $(1.04 \mathrm{mg} / \mathrm{kg})$ as shown in Figure 7.

The concentration of lead $(\mathrm{Pb})$ were observed in organs of the frog (intestine, skin and liver), with liver showing the highest concentration of $1.89 \pm 1.45 \mathrm{mg} / \mathrm{kg}$.

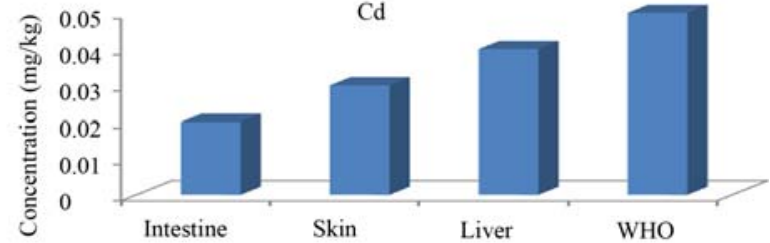

Figure 6. Distribution of cadmium in the organs of Rana esculenta from River Guma.

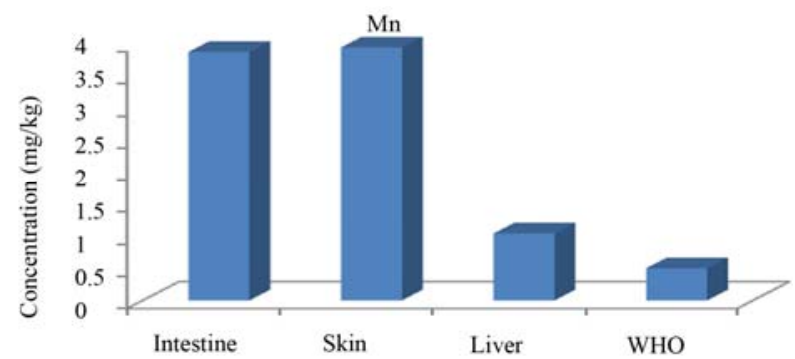

Figure 7. Distribution of manganese in the organs of Rana esculenta from River Guma.

Eneji, et al. [11], reported $3.58 \mathrm{mg} / \mathrm{kg}$ and $2.759 \mathrm{mg} / \mathrm{kg}$ of $\mathrm{Pb}$ in $T$. zilli and C. gariepinus from River Benue. Emmanuel, et al. [4] reported $\mathrm{Pb}$ to be $35.36 \mathrm{ppm}$ in Rana esculentus and $5.39 \mathrm{ppm}$ of $\mathrm{Pb}$ in Crabs from Alaro Sream Ecosystem, Ibadan. Vinodhini, et al. [3] reported $6.76 \mu \mathrm{g} / \mathrm{g}$ of $\mathrm{Pb}$ in Cyprinus carpio. In amphibians, $\mathrm{Pb}$ exposure has resulted in a range of effects including decrease erythrocytes and leucocytes, neutrophils and monocytes, sloughing of the skin, excessive bile secretion, hypertrophy of liver, spleen and stomach, decreased muscle tone and loss of normal semi-erect posture, salivation, excitement and muscular twitching; and delayed metamorphosis [13]. The result of the analysis revealed that the concentration of lead in intestine, skin, liver (frog), were higher than the permissible limit of 0.01 $\mathrm{mg} / \mathrm{L}$ [14].

The highest copper concentration was found in the liver $(0.68 \pm 0.20 \mathrm{mg} / \mathrm{kg})$ and the least value was observed in the intestine $(0.04 \pm 0.04 \mathrm{mg} / \mathrm{kg})$. No copper concentration was observed in skin. Eneji, et al. [11] reported $5.89 \mathrm{mg} / \mathrm{kg}$ and $9.99 \mathrm{mg} / \mathrm{kg}$ of $\mathrm{Cu}$ in Clarias gariepinus and Tilapia zilli from River Benue. Emmanuel, et al. [4] reported $21.7 \mathrm{ppm}$ and $68.1 \mathrm{ppm}$ of $\mathrm{Cu}$ in Rana esculentus and Crabs from Alaro Stream Ecosystem, Ibadan. $\mathrm{Cu}$ is essential for good health, but very high intake can cause health problems such as liver and kidney damage [15]. Copper normally occurs in drinking water from pipes, as well as from additives designed to control algal growth. In humans, ingested copper from foods stored in copper vessels might cause intestinal discomfort, dizziness and headaches, while excess accumulation of copper in liver may result in hepatitis or cirrhosis and in a hemolytic crisis similar to that ob- 
served in acute copper poisoning [16]. However, none of the samples in this study had copper content exceeding the maximum permissible limit of $2 \mathrm{mg} / \mathrm{L}$ [14].

Zinc concentration was found to be higher in the intestine of frog $(1.81 \pm 0.20 \mathrm{mg} / \mathrm{kg})$. Eneji, et al. [11] reported $18.05 \mathrm{mg} / \mathrm{kg}$ of $\mathrm{Zn}$ in T. zilli and $17.76 \mathrm{mg} / \mathrm{kg}$ of $\mathrm{Zn}$ in C. gariepinus from River Benue. Emmanuel et al. [4] reported $29.84 \mathrm{ppm}$ of $\mathrm{Zn}$ in Rana esculentus and $32.97 \mathrm{ppm}$ in Crabs from Alaro Stream Ecosystem, Ibadan. Ololade, et al. [17] reported $0.61 \mathrm{mg} / \mathrm{kg}, 0.23$ $\mathrm{mg} / \mathrm{kg}$ and $0.10 \mathrm{mg} / \mathrm{kg}$ of $\mathrm{Zn}$ in crab, fish and periwinkles, respectively. $\mathrm{Zn}$ is essential in nutrition and has low toxicity level; however, high level of $\mathrm{Zn}$ is harmful to human health [15]. The concentrations of $\mathrm{Zn}$ in all the samples studied were below the permissible limit of 5 $\mathrm{mg} / \mathrm{L}$ set by WHO [14].

The concentrations of Chromium were observed in intestine, skin and liver as presented in Table 1; with highest concentration of chromium found in intestine $(0.11 \pm$ 0.03). Eneji, et al. [11] reported $92.9 \mathrm{mg} / \mathrm{kg}$ of $\mathrm{Cr}$ in $T$. zilli and $88.5 \mathrm{ppm}$ of $\mathrm{Cr}$ in C. gariepinus from River Benue. Chromium is an essential dietary requirement in limited amounts and a deficiency can lead to disruption of glucose metabolism. Indeed, it has been reported that chromium deficiency is of greater nutritional concern than overexposure. However, it is considered that chromium is carcinogenic at high concentration levels. The concentration of chromium in the skin and liver were less compared with the intestine which was above the permissible limit of $0.07 \mathrm{mg} / \mathrm{L}$ [14].

The concentrations of iron (Fe) in the intestine, skin, liver (organs of frog), show a significant variation among the organs of the frog (intestine, skin and liver). The results indicate that the liver contains the highest concentration of Fe (113.72 $\pm 2.76 \mathrm{mg} / \mathrm{kg})$, followed by the skin $(76.10 \pm 46.00 \mathrm{mg} / \mathrm{kg})$ while the intestine contains 63.03 $\pm 38.12 \mathrm{mg} / \mathrm{kg}$ of Fe. Iron level of $68.68 \mathrm{mg} / \mathrm{kg}$ and $113.1 \mathrm{mg} / \mathrm{kg}$ was reported from investigation on $T$. zilli and C. gariepinus from River Benue by Eneji, et al. [11]. Also Ololade, et al. [17] reported $42.01 \mathrm{mg} / \mathrm{kg}, 204.72$ $\mathrm{mg} / \mathrm{kg}$ and $1315.5 \mathrm{mg} / \mathrm{kg}$ Fe in Crab, Fish and Periwinkles from marine seafood. Iron is essential in nutrition and has low toxicity level. Excessive intake of iron may increase susceptibility to infection [18]. Ingestion accounts for most of the toxic effects of iron because iron is absorbed rapidly in the gastrointestinal tract. The corrosive nature of iron seems to further increase the absorption. Most overdoses appear to the result of children mistaking red-coated ferrous sulfate tablets adult multivitamin preparations for candy. The concentration of iron in the sample analyzed is above the permissible limit of $0.3 \mathrm{mg} / \mathrm{L}$ [14].

The highest concentration of Cadmium was observed in the liver of frog $(0.04 \pm 0.01 \mathrm{mg} / \mathrm{kg})$, Table 1 , while the lowest concentration was found in the intestine (0.02 $\mathrm{mg} / \mathrm{kg}$ ) of the frog. The skin, have the concentrations of $0.03 \mathrm{mg} / \mathrm{kg}$. Eneji et al. [11] reported $0.994 \mathrm{mg} / \mathrm{kg}$ of Cd in T. zilli and $0.927 \mathrm{mg} / \mathrm{kg}$ of Cd in C. gariepinus from River Benue. Cadmium is not essential in nutrition but has high toxicity. Its toxicity effects are felt in the form of high blood pressure, kidney damage and red blood cells loss. From the results of this study, the cadmium concentration in the samples studied was found to be less than the $0.05 \mathrm{mg} / \mathrm{L}$ permissible limit set by WHO [14].

The concentrations of manganese in the intestine, skin, liver are: $(3.87 \pm 3.58 \mathrm{mg} / \mathrm{kg})$, $(3.94 \pm 0.97 \mathrm{mg} / \mathrm{kg})$ and $(1.04 \pm 0.21 \mathrm{mg} / \mathrm{kg})$. The highest Mn concentration was observed in the skin of frog $(3.94 \pm 0.97 \mathrm{mg} / \mathrm{kg})$. Ololade, et al. (2008) reported $2.18 \mathrm{mg} / \mathrm{kg}, 1.05 \mathrm{mg} / \mathrm{kg}$ and 0.78 $\mathrm{mg} / \mathrm{kg}$ of Cd in crab, fish and periwinkles. Eneji, et al. [11] reported $7.818 \mathrm{mg} / \mathrm{kg}$ of $\mathrm{Mn}$ in T. zilli and 3.507 $\mathrm{mg} / \mathrm{kg}$ in C. gariepinus from River Benue. Manganese is needed in small amounts for growth and good health in humans; otherwise, deficiency of Mn can cause nervous system problems [19]. In the samples studied, the concentrations of manganese were found to be higher than maximum permissible limit of $0.5 \mathrm{mg} / \mathrm{L}$ set by WHO [14].

\section{Conclusion}

From the study, the concentrations of all the metals in the liver, skin and intestine of frog were found to be statistically significant. Generally, the levels of lead, chromium, iron and manganese in all the organs were above the tolerance limits with exception of cadmium, copper and zinc that were below the tolerance limits in all the samples. The trend of the heavy metals concentration in the organs can be represented as: $\mathrm{Fe}>\mathrm{Mn}>\mathrm{Pb}>\mathrm{Zn}>\mathrm{Cu}>$ $\mathrm{Cr}>\mathrm{Cd}$.

\section{Acknowledgement}

Our appreciation goes to Professor Rufus Sha'Ato, Miss Utibe and Mr Peter Onuwa for their useful advice and assistance during sampling. We are also grateful to the technical staff of NARICT for their assistance during the analysis.

\section{REFERENCES}

[1] E. G. Alirzayeva, T. S. Shiryan, M. A. Yazici, S. M. Alverdiyeva and V. M. Cakmale, "Heavy Metal Accumulation in Artemisia and Foliaceous Lichen Species From The Azerbaijan Flora,” Forest Snow And Landscape Research, Vol. 80, No. 3, 2006, pp. 339-348.

[2] S. Bakidere and M. Yaman, "Determination of Lead, Cadmium, Copper in Roadside Soil and Plants in Elazig, Turkey," Environmental Monitoring and Assessment, Vol. 136, No. 1-3, 2008, pp. 401-410. 


\section{doi:10.1007/s10661-007-9695-1}

[3] R. Vinodhini and M. Narayanan, "Bioaccumulation of Heavy Metals in Organs of Fresh Fish Cyprinus carpio (common carp)," International Journal of Environmental Science and Technology, Vol. 5, No. 2, 2008, pp. 179182.

[4] T. T. Emmanuel and G. O. Tonye, "Macro and Trace Element Accumulation in Edible Crabs and Frogs in Alaro Stream Ecosystem, Ibadan, Nigeria," Journal of Research in National Development, Vol. 9, No. 2, 2011, pp. 1596-8308.

[5] M. Canbek, T. A. Demir, M. Uyanoglu, G. Bayramoglu, O. Emroglu, N. Arslan and O. Koyuncu, "Preliminary Assessment of Heavy Metals in Water and Some Cyprinidae Species from Porsuk River, Turkey," Journal of Applied Biological Sciences, Vol. 1, No. 3, 2007, pp. 8993.

[6] M. A. I. Chukwujindu, E. N. Godwin and O. A. Francis, "Assessment of contamination by heavy metals in Sediments of Ase River, Niger Delta, Nigeria," Research Journal of Environmental Sciences, Vol. 1, 2007, pp. 220-228.

[7] J. C. Akan, F. I. Abdulrahman, O. A. Sadipo and Y. A. Chiroma, "Distribution of Heavy metals in the Liver, Kidney and Meat of Beef, Mutton, Caprine and Chicken from Rasuwan Shanu Market in Maiduguri Metropolis, Borno State, Nigeria," Research Journal of Applied Sciences, Engineering and Technology, Vol. 2, No. 8, 2010, pp. 743-748.

[8] E. S. Ilona, S. T. Anush and P. P. Yurv, "Effect of Molybdenium, Chrome and Cadmium Ions on Metamorphosis and Erythrocytes Morphology of the Marsh Frog pelophylax ridibundus (Amphibia: Anura),” Journal of Environmental Science and Technology, Vol. 4, No. 2, 2011, pp. 172-181. doi:10.3923/jest.2011.172.181

[9] S. Luo, M. C. Plowman, S. M. Hopfer and F. W. Sunderman Jr., " $\mathrm{Mg}^{2+}$ deprivation enhances and $\mathrm{Mg}^{2+}$ supplementation diminishes the embryo toxic and teratogenic effects of $\mathrm{Ni}^{2+}, \mathrm{Co}^{2+}, \mathrm{Cd}^{2+}$ for frog embryos in the FETAX Assay,” Annals of clinical and laboratory science, Vol. 23, No. 2, 1993, pp. 121-129.

[10] I. S. Eneji, "Spatial and Temporal Variation in the Heavy Metals Loading of River Benue in Makurdi Metropolitan Area,” PhD Thesis, Department of Chemistry, University of Agriculture, Makurdi, 2010, pp. 1-234.
[11] I. S. Eneji, R. Sha’Ato and P. A. Annune, "Bioaccumulation of Heavy Metals in Fish (Tilapia zilli and Clarias gariepinus) Organs from River Benue, North-Central Nigeria," Pakistan Journal of Analytical and Environmental Chemistry, Vol. 12, No. 1-2, 2011, pp. 25-31. doi:10.1021/ac50057a034

[12] J. E. Poldoski, "Determination of Lead and Cadmium in Fish and Clam Tissue by Atomic Absorption Spectrometry with a Molybdenum and Lanthanum Treated Pyrolytic Graphite Atomizer,” Analytical Chemistry, Vol. 52, No. 7, 1980, pp. 1147-1151.

[13] D. W. Sparling, G. L. Linder and C. A. Bishop, "Ecotoxicology of Amphibians and Reptiles. Society of Environmental Toxicology and Chemistry," 2nd Edition, Parsacola, Fla, 2000, p. 877

[14] World Health Organisation, "Regulation Standards Environmental Harzards of Heavy Metals: Summary Evaluations of $\mathrm{Pb}, \mathrm{Cd}$ and $\mathrm{Hg}$," Environmental Health Criteria 20, Geneva, 1995

[15] Agency for Toxic Substances and Disease Registry (ATSDR), "Division of Toxicology, Clifton Road, NE, Atlanta, GA,” 2004.

http://www.atsdr.cdc.gov/toxprofiles/

[16] M. A. Johnson, “Copper,” In: R. Macrae, R. K. Robinson and M. J.Sadler, Eds., Encyclopaedia of Food Science, Food Technology and Nutrition, Vol. 1, Academic Press, London, 1993, pp. 713-718

[17] I. A. Ololade, L. Lajide, I. A. Amoo and N. A. Oladoja, "Investigation of Heavy Metalcontamination of Edible Marine Seafood," Africa Journal of Pure and Applied Chemistry, Vol. 2, No. 12, 2011, pp. 121-131.

[18] Nigerian Industrial Standard (NIS), "Nigerian Standard for Drinking Water Quality,” 2007.

[19] D. Demirezen and K. Uruc, "Comparative Study of Trace Elements in Certain Fish, Meat and Meat Products," Meat Science, Vol. 74, No. 2, 2006, pp. 255-260. doi:10.1016/j.meatsci.2006.03.012 